\title{
Assessment from space of mangroves evolution in the Mekong delta, in relation with extensive shrimp-farming
}

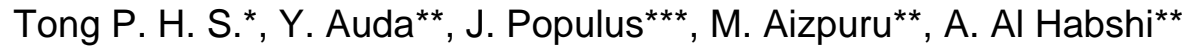 \\ and F. Blasco**
}

\author{
*Institute of Oceanography, Dpt of Marine Botany, 1 Cau Da Street, Nhatrang, Viet Nam. E-mail: \\ gishaiduong@dng.vnn.vn \\ **Remote Sensing Centre, Laboratory of Terrestrial Ecology, 13 Avenue du Colonel Roche, B.P. 4072, \\ 31029 Toulouse Cedex 4, France. E-mail: Francois.Blasco@cict.fr \\ ***IFREMER, BP 70, 29280 Plouzané, France. E-mail: jpopulus@ifremer.fr
}

\begin{abstract}
:
This study is an attempt to produce an assessment of the impact of shrimp aquaculture in the Mekong Delta (Viet Nam) on mangrove ecosystems. For this exercise we selected two sub-areas (Ca Mau and Tra Vinh provinces) encompassing a variety of land uses and ecological conditions. Twenty stations in Tra Vinh and 15 stations in Ca Mau have been surveyed several times from September 2000 to March 2002. Field investigations included mangrove soils studies, measurements of $\mathrm{pH}$ and salinity of the water, analysis of mangrove flora, and density and structure of the vegetation. Four Système Probatoire de l'Observation de la Terre (SPOT) scenes were used for the discrimination of mangrove types and for the delineation of landscape units. For the first time, five ecologically distinct landscape classes were identified and delineated. Their possible links with the farming and yields of high valued species of shrimps, especially the giant tiger shrimp (Pencteus monodon) destined for export markets, need further studies. Since 1965, about 30\% of mangrove ecosystems have been lost in Ca Mau Province and more than $30 \%$ of present mangroves are replanted monospecific stands. To the best of our knowledge, this is the first study which demonstrates that, in spite of deep and ancient man interactions in the Mekong Delta, five ecologically distinct classes of land use can be defined. Satellite surveys confirm a clear distribution of landscape units with possible links with shrimp aquaculture potentialities.
\end{abstract}




\section{INTRODUCTION}

The work presented here is a contribution to a joint project (Gambas), between IFREMER, the Institute of Oceanography, Nha Trang (Viet Nam) and the EEC, concerning environmental sustainability of brackish water aquaculture in the Mekong River delta, where shrimp farming became unsustainable about 10 years ago, as a result of the outbreak of viral diseases and possibly also to large scale mangrove forest destruction accompanied by major environmental changes. The main goal of the work described here is to analyse the discrimination or otherwise of shrimp ponds, mangroves and other major land-use components in the Mekong River delta using optical, infrared SPOT data. The ultimate objective is to try to establish links between present land-use classes, the evolutionary trends of mangrove forest ecosystems and shrimp aquaculture potentialities. Extensive ground truth data have been obtained during several field trips (10-20 September 2000, 14-28 March 2001, 6-23 September 2001 and 2-20 March 2002). 36 field stations (16 in Ca Mau Province and 20 in Tra Vinh Province) were selected and revisited, each of them hosting shrimp farms with distinct aquatic properties (tidal amplitude, distance to sea shore, water salinity, shrimp farming practices etc.) and distinct terrestrial ecology (mainly distinct mangrove and soil types).

\section{THE STUDY AREA}

The study area in the Mekong River delta is an almost flat region, densely populated and intensively farmed. It is approximately centered on the city of Can Tho $\left(10^{\circ} 03^{\prime} \mathrm{N}\right.$, $105^{\circ} 46^{\prime} \mathrm{E}$, figures 1,2 and 3). As shown in figure 4, the average climatic conditions are moist tropical with a short dry season (January to March) and a continuous rainy season from April-May to November-December. Catastrophic floods often occur in October and in April especially when cyclonic storms affect this part of Viet Nam. Paddy fields are the most conspicuous land-use unit in the landscape along with shrimp ponds, salt pans and mangroves.

The present geomorphological context results from a set of sedimentary and erosion processes which are about 2500 years old (Thuyen 1996). As shown in figure 1, accretion processes have been much more pronounced in Ca Mau Province than in Tra Vinh Province.

\section{[Insert figures 1, 2, 3 and 4 about here]}

In fact, the southern tip of the Ca Mau peninsula receives the sediments from the South China Sea, brought by coastal currents. Some of these solid particles, mainly loamy and clayey, are also transported by the main channel (Cua Lon) towards the West Coast (Gulf of Thailand). In Tra Vinh Province, between the main arms of the Mekong river (Co Chien and Hau Giang), the geomorphological setting is different. It is composed of sandy ridges, separated by depressions where clay and organic matter accumulate. The Mekong delta is at present criss-crossed in all directions by about 6,000 km of large channels and 3,000 km of secondary canals.

Large transversal channels (Lang Chim at Tra Vinh and Cua Lon at Ca Mau) receive influences both from the South China Sea and from the Gulf of Thailand, leading to extremely complex waters interactions which are not fully understood in the different parts of the delta. In the South China Sea, the tidal regime is semi-diurnal 
with a tidal amplitude about 2.2 to $3 \mathrm{~m}$ on the coast. In the Gulf of Thailand, tides are diurnal with an amplitude of 1 to $2 \mathrm{~m}$. This complexity of sea water circulation in channels, canals and in mangrove ecosystems determines two little known ecologically important parameters in each point of the delta i.e.: the duration of flooding and the salinity of brackish waters and soils. Soils are mainly clayey-loamy (at least 95\%) and the organic matter content may vary considerably, from less than $5 \%$ to about 35\%. Mean pH values are generally included between 6 and 8 . This means that acid sulphate soils, which are generated when mangrove soils are oxidised by human activities (dredging, shrimp ponds constructions etc.), are uncommon in the study areas. However acid sulphate soils occupy more than $40 \%$ in the northern part of the delta, lowering the local $\mathrm{pH}$ of drainage water to 3 (Minh et al. 1997).

Several authors (Alongi et al. 1999, 2000, Johnston et al. 1999) assume that major ecological and commercial problems such as salinity intrusion, acidification of coastal and aquaculture waters, the decline in abundance of post-larval shrimp and crab and a decline in shrimp pond yields are largely related to the depletion or removal of mangroves especially between 1990 and 1996. In practically all aquacultural systems, operators clearfell the mangrove forest and construct small dykes, with sluice gates to retain water. The original tidal regime, which is essential for the survival of mangrove trees species, is totally disturbed. In the Mekong delta, while the size of individual shrimp ponds range from about 0.1 to 1 ha in size, thousands of hectares of continuous ponds have been built. With the exception of planted mangrove forests, in areas where the tidal regime is approximately restored, most of the mangrove flora and fauna hardly survive in shrimp ponds areas, because of drastic changes in drainage conditions, in tidal frequency and in nutrients availability.

Table 1 summarises important data on soil properties in Ca Mau and Tra Vinh Provinces.

\section{(Insert table 1 about here]}

\section{BACKGROUND TO THE PRESENT STUDY}

This part of the world is unique in many ways. This long stretch of moist tropical coastland, from Vung Tau Cape to Ha Tien (figure 1), which constitutes the Mekong delta, has one of the largest deltaic plains, covering about 100,000 km² (ranking third, after the Amazon River and the Ganges). In theory, its board macro-ecological, geomorphological and hydrological conditions are extremely favourable for the development of luxuriant mangroves which have been converted, in many places, to paddy fields, since historical times (figure 2 and 3 ).

During the French colonial period, until 1943, luxuriant mangroves still covered about $4,000 \mathrm{~km}^{2}$ in this area, of which about $1,500 \mathrm{~km}^{2}$ were found in Ca Mau Province and $400 \mathrm{~km}^{2}$ in Tra Vinh Province (Maurand 1943, Moquillon 1950). Since the mid-1950s, some interesting figures concerning the depletion of these ecosystems have been published (Hong and San 1993, Tri et al. 1998, Phan Minh Thu 2002). During the last war (1962-1971), the mangroves of Ca Mau Province (formerly Minh Hai Province, lately divided in Ca Mau and Bac Lieu) became one of the major 
targets of herbicides, defoliants and napalm, especially between 1965 and 1969 (NAS 1974, Ross 1975, Teas and Kelly 1975).

This was a unique case of mass military use of herbicides on a natural ecosystem. The post-war period was marked by an increased destruction of the remaining mangroves, due to the fact that over-fishing in coastal waters led to a rapid decline of shrimp capture and consequently, mangroves have been increasingly destroyed for shrimp farming. Since 1981, cultured shrimp production in this delta (several species of Penaeus, the most important being P. monodon) has increased from 200 tons. $^{-1} \mathrm{r}^{-1}$ to nearly 80,000 tons in 1992 and more than 150,000 tons in 2002 (Nguyen Tac An 2002, figure 5). This caused major changes in drainage patterns and in tidal flooding frequency. In the mean time, natural mangrove ecosystems were shrinking and new artificial mangroves were being massively planted with one species of trees (Rhizophora apiculata Blume) and a palm-like Nypaceae (Nypa fruticans van Wurmb.).

\section{[Insert figure 5 and table 2 about here]}

\section{PREVIOUS WORKS}

Mangroves can be defined as an association of trees and shrubs forming the dominant vegetation in tidal, saline wetlands, along tropical and subtropical coasts (Tomlinson 1986, Ricklefs and Schluter 1993). In Viet Nam as elsewhere in the world, mangroves are considered as most important ecosystems (high standing biomass, coastal protection, high primary productivity, narrow links with coastal fisheries etc.) (Odum and Heald 1972, Lugo et al. 1980, Snedaker et al. 1998, Saenger 2002). Several authors and international organisations have demonstrated their ecological, social, cultural and economical values (Field 1996). It is assumed that one hectare of mangrove forest supports a sustainable shrimp production about $350 \mathrm{~kg} \cdot \mathrm{ha}^{-1} \cdot \mathrm{yr}^{-1}$ (Hambrey 1996, De Graaf and Xuan 1998, Saenger 2002).

Several studies have been recently devoted to the macro-ecology of mangroves in the Mekong delta and possible links between mangrove clearance, coastal fisheries, shrimp farming and its sustainability (Primavera 1998, De Graaf and Xuan 1998, Alongi et al. 1999, Clough et al. 1999, Ronnback 1999, Johnston et al. 2000, Ellison 2002). With the exception of a recent unpublished thesis (Phan Minh Thu 2002), the applications of satellite remote sensing to mangrove and shrimp-farming management in the Mekong delta seem to have been neglected, although coastal resources in this part of the world are very intensively used. As an adequate evaluation of mangrove resources is not available, it has resulted in conflicting goals of conservation, economic activities and sustainable development. When shrimp farming activity collapses, the conflicts with other uses (paddy, salt, timber and wood, fisheries etc.) are amplified and the crisis is spreading. In 2002, 8,000 families were without work in central Mekong (Phan Minh Thu 2002). The results given in table 2 show that production and productivity of shrimps declined rapidly in 1996, 1997 and 1998 due to the outbreak of shrimp viral diseases and poor water quality. Since 1998, both production and productivity have been improving regularly, at the same time strict mangrove management practices and protection are were implemented.

Remote sensing technology is one of the most efficient tools in the assessment of coastal resources. Since the launching of the first high resolution satellite (SPOT in 
1986), the discrimination and mapping of mangroves has become more widespread in most tropical and sub-tropical countries (Aschbacher et al. 1995, Blasco et al. 1997, Spalding et al. 1997, Green et al. 1998, Dwivedi et al. 1999, Gao 1999, Phinn et al. 2000, Sanderson 2001 etc.). Although no detailed vegetation mapping has been published for the Mekong delta, it is known that originally, mangrove communities were very extended in the delta, and floristically and structurally very diversified (Moquillon 1950). In recent plantations, the floristic composition is almost uniform, with only one native species (Rhizophora apiculata) constituting narrow, dense low forests $\left(5,000\right.$ trees.ha- $\left.^{-1}\right)$, bordering shrimp ponds. We have not been able so far to determine the structural properties of these artificial woody ecosystems from space data, primarily because the available instruments generate a signal only in each of a small number of very broad bands. It is implicit that permanent global monitoring of mangroves, at high spatial resolutions (Landsat TM, SPOT HRV and HRVIR, IRS1CLISS-III, ERS etc.) is practically not feasible and that local mangrove monitoring at low spatial resolution (NOAA-AVHRR, SPOT-VEGETATION) is also impossible (Malingreau et al. 1989, Justice et al. 1985, Townshend and Justice 1986). ERS-2 synthetic aperture radar has been tested in Mekong delta for the delineation of rice cropping systems (Le Toan et al. 1997, Liew et al. 1998), but neither optical sensors nor microwaves have been tested in this part of the world for mangrove studies and inventory. Previous multitemporal studies carried out on paddy fields in the Mekong delta have shown that the radar backscatter generally increases with time after planting when there is a rapid increase in plant biomass (Liew et al. 1998). The backscatter saturates at the end of the growing season, when the green crop reaches its highest density. The backscatter coefficient increases from $-16 \mathrm{~dB}$, when the fields are inundated and recently planted (low standing biomass), to about $-8 \mathrm{~dB}$, at the saturation level coinciding with the maximum plant development (Le Toan et al. 1997).

\section{FIELD SURVEYS AND MAIN LANDSCAPE COMPONENTS}

Extensive ground truth data have been obtained during four field trips (10-20 September 2000, 14-28 March 2001, 6-23 September 2001 and 2-20 March 2002). 36 field stations (16 in Ca Mau Province and 20 in Tra Vinh Province) were selected and revisited, each of them hosting shrimp production farms with distinct aquatic properties (tidal amplitude, distance to sea shore, water salinity etc.) and distinct terrestrial ecology (mainly a variety of mangrove and soil types). Measurements were made in situ or in laboratories in Nha Trang (Viet Nam), Toulouse and L'Humeau (France). Each station has been properly located using a GPS (Garmin e Trex Summit), in order to correlate ground truth with satellite data. Field measurements concerned:

- Surface and bottom water samplings and studied parameters: $\mathrm{pH}$, temperature, salinity, dissolved oxygen, pico-plancton and heterotrophic bacteria by flux cytometry, chorophyll-a in water etc.). All these data were needed for establishing relationships between shrimp production and aquatic ecological factors but they are not essential for remote sensing data interpretation. They are not detailed here except salinities and $\mathrm{pH}$ values in water and soil. These data are selective regarding the choice of mangrove trees to be planted and the species of 
shrimps to be grown. The salinity was measured with an hand refractometer (Euromex RF 360).

- Concerning mangrove forests, in addition to forestry products, benefits in the Mekong delta are: help protect coast and river bank from erosion, trap sediments and build new land, provide nursery and feeding ground for many species of animals of commercial value, produce a high amount of primary production and litter that support coastal food chains etc. We studied their structure, density, height, floristic composition and standing biomass. None of these parameters could be measured from space. As the weight of organic matter of each tree, dry weight is usually related to its $\mathrm{DBH}$ (diameter at breast height, $1.3 \mathrm{~m}$ above ground), we used a simple non linear relationship (dry weight $=\mathrm{A} \times \mathrm{DBH}^{\mathrm{B}}$ ) where $\mathrm{A}$ and $\mathrm{B}$ are constant (respectively 0.1560 and 2.5538 for stems and branches). In mangrove plantations, where all trees are of the same age, the simplest approach is to measure the average $\mathrm{DBH}$ and to compute the dry weight and the volume of an average tree and to multiply by the stand density to estimate the stand biomass. Naturally figures vary considerably according to the age and density of each stand. Young stands of Rhizophora apiculata may have up to 20,000 stems per hectare, although a 20 years old stand usually has no more than 2,000 stems. In a planted mangrove with $R$. apiculata, with mean tree diameter about $10 \mathrm{~cm}$ and tree height $8 \mathrm{~m}$, the total standing biomass per tree averaged $398 \mathrm{~kg}$. Regarding plantations of Rhizophora apiculata Blume, the initial planting density was of 20,000 ha-1. Since a few years, the Forest Department suggests to reduce the planting density to $10,000 \mathrm{ha}^{-1}$, thinning to $5,000 \mathrm{ha}^{-1}$ at 7-8 years and thinning again at 12 years to a density of 2,000 ha-1. The final harvest which should be at 20 years, is often reduced to 15 years for economic reasons, as most farmers try to reduce their concern about having to wait so long for a return from their forestry products. These mangrove products are primarily used as a sustainable source of fuel wood and charcoal to meet the increasing needs for domestic fuel. In addition, they are usually important construction components (beams and poles for buildings, dock pilings etc.).

Soils characteristics were also recorded during field surveys.

Most paddy fields are usually dry from December to March. During this short period of the year, they cannot be confused neither with shrimp ponds nor with mangroves, with high resolution satellite data. From May to December, paddy fields are under water, bearing green vegetation. During this long period of nearly eight to nine months, the confusion between paddy fields and shrimp ponds or between paddy fields (at the end of the growth cycle) and mangroves is almost permanent.

In areas where irrigation facilities are available, three paddy crops per year are possible and the cropping calendar may change from one year to another depending on the monsoon onset. In addition, some cropping systems combine paddy cultivation and shrimp ponds.

\section{REMOTE SENSING, ANCILLARY DATA AND METHOD}

Main satellite data used in this study are: 2 SPOT-4 HRVIR imageries respectively covering Ca Mau region (274-332, at the end of the dry season) and Tra Vinh region (276-330 at the beginning of the dry season). Both of them were processed at SPOT- 
Image Company on level 2A (UTM Projection). These data characteristics are summarised in table 3.

\section{[Insert table 3 about here]}

Green and red bands are mainly used here for the study of green vegetation which strongly absorbs these radiation. The near infrared band is sensitive to the structure of the leaf; it is also commonly used for vegetation analysis because it is strongly reflected by dense green vegetation. Short wave infrared band is sensitive to water conditions in leaves as well as on the top-soil. SPOT data are now almost routinely used for coastal research activities.

Thanks to GPS data collected during the field trip, these satellite products have been georeferenced and each station was properly located. The method of the nearest neighbour is used. The RMS error computed for an adjustment by a polygon of degree 1 is smaller than $50 \mathrm{~m}$, for both images. The first georeferencing attempts from the US navy maps (1962-1967) has shown an important shifting (about 400m) between the data provided by the GPS and the coordinates given by these maps.

The images were analysed at the Remote Sensing Center, Laboratoire d'Ecologie Terrestre, in Toulouse (France), using IDRISI and ENVI softwares. Figure 6 summarizes the adopted methodology and the main successive steps.

\section{[Insert figure 6 about here]}

We also used, as base maps, a series of topographic maps produced by the US Navy maps (1962-1967) at 1:50,000 scale, Transverse Mercator Projection, covering Ca Mau Province in four sheets and Tra Vinh Province in two sheets. On the other hand, we had access to digitized forest maps established at 1:50,000 scale by the Forestry and Planning Institute in Hanoi (1997-1998).

\section{SPOT data analysis}

The following approaches were used based on visual and digital processing of the images. A visual interpretation was used to identify and to delineate conspicuous homogeneous land-use units through tint, texture, morphology, environment and contrast effects. This approach led to a provisional classification that formed the basis for a supervised digital classification (Maximum Likelihood). The supervised automated classification was carried out, based on training areas delineated after the visual interpretation. The selected training areas were drawn from a chosen subscene which has been considered as sufficiently representative of the main land-use units included in the whole image. Then, all the sub-scenes were classified from the same training areas, and later assembled. Two classifying modes, Minimum Distance and Maximum Likelihood, were used and compared with each other. Best results were obtained with the Maximum Likelihood classifier, with an average accuracy nearing $80 \%$ according to available ground truth data and to the forest map already mentioned (1:50,000 scale), which was used for the validation of the results, especially in areas where field surveying was virtually impossible because of the absence of roads or accessible waterways. 


\section{Mangrove and shrimp pond detection method}

A specific goal of the present study was to characterise and to discriminate the present distribution of shrimp ponds and mangroves which are often intermingled in the so called «Mixed shrimp-mangrove forestry farms». In the field, a shrimp pond is a water rectangular surface, less than one meter deep, covering about 1 to 10 hectares. Dense planted or natural mangrove forests are usually well delineated from a simple visual interpretation of a color composite. This is not the case with shrimp ponds, which can be easily confused with flooded paddy fields. It was decided to apply a specific extraction method (Gond et al. 2001), in order to have a more reliable sampling of existing shrimp ponds before the supervised classification is performed. The test has been carried out in Tra Vinh Province, with recent SPOT 4 data collected during the dry season (January 2001). The general hypothesis is that the SWIR channel $(1.58-1.73 \mu \mathrm{m})$ is absorbed by water, either by free water bodies or by the water contents in leaves cells. A Normalized Difference Water Index (NDWI) can be easily computed (NDWI = NIR-SWIR / NIR+SWIR). The classical Normalized Difference Vegetation Index (NDVI = NIR-Red / NIR+Red) was also computed for the same areas in order to extract mixed pixels corresponding to shrimp ponds in which some aquatic plant species are thriving. The difference between NDWI and NDVI strengthens and highlights the existing free water bodies on the images, with and without aquatic vegetation.

Technically the adopted procedure can be summarised as follows: (1) computation of the NDWI and the NDVI and their difference, (2) all values higher than -0.08 and lower than 0.08 correspond to Water bodies, (3) stretching on the channel SWIR separately and thresholding (-0.05 to 0.05$),(4)$ merging these results together through an "AND" function which selects those pixels satisfying both conditions. The output of these data have been used for the selection of training areas.

SPOT scene interpretation gives way to a clear zonation of main landscape units and to the identification and delineation of training areas. The classification itself produces an automatic discrimination of 6 classes given in figure 7 .

\section{RESULTS}

- Maximum Likelihood classification (figure 7)

The commonest confusion and mis-classified pixels belong to three main sets: 'dense mangroves and orchards', 'flooded paddy fields and shrimp ponds', 'recently planted mangroves', 'flooded paddy fields and shrimp ponds with some green vegetation'.

These results require obvious methodological and conceptual improvements, including multidate approaches. This implies much additional processing work with the hope that the global accuracy of the classification could reach up to $90 \%$.

At this stage we decided that this first attempt obtained with a limited amount of satellite data was sufficiently accurate $(80 \%$ of well classified pixels) for the production of the first automated land-use map produced using MAPINFO Geographic Information System.

The GIS proceeds by:

- geometric correction of the SPOT image level 2A with reference to the topographic maps;

- delineation of the intertidal zone from the combination of Vegetation and

Brightness indices; 
- digitisation of the thematic classes obtained with the Maximum Likelihood classifier (creation of the cartographic database);

- validation of main classes with field data and colour graphic print-out of the results.

\section{[Insert figure 7 about here]}

\section{Colour composite interpretation}

As shown in figures 8 and 9, one of the most important result of this study is the delineation from space of five land-use classes, each of them having very distinct biophysical properties in terms of crops, forestry, ecology, soils and management.

\section{[Insert figures 8 and 9 about here]}

Class I: Harvested paddy fields and orchards. This is mainly an extensive rice producing part of the delta, located outside mangrove areas. Brackish waters are controlled thanks to sluices and the salinity of water entering paddy field is extremely low ( $<3 \%$ in irrigation channels). A progressive conversion of some paddy fields into mixed land-uses (i.e. paddy during the rainy season, shrimp culture during the dry season) cannot be easily detected on satellite images. In Ia (figure 8), the greatest majority of paddy fields are dry and harvested during the dry season (January to March). This explains their high reflectance observed in each wavelength. The general colour of soils is pale grey with high loam, fine sands and clay contents.

Very conspicuous pinkish lines in figure 8 are mainly determined by the spectral responses of orchards and human settlements in between large crop lands. Although the woody vegetation in orchards is rather dense, its reflectance does not induce a strong response in the infra-red. This is often the case, during the dry season, perhaps because broadleaves are often coated with a thin layer of dust. Some bluish patches, observed in Class I, are those of burned paddy straws.

In class Ib, the landscape is almost the same as in Ia but the phenology of paddy fields, cropping cycles and fields size are different. The strong red spectral response is due to the strong reflectance of dense, young crops, in the near infrared. Here also, some paddy straws remain standing after the harvest and can be burned. In this part of the image, three rice crops per year can be expected.

Class II: Shrimp ponds, salt pans and mangrove remnants. In Tra Vinh Province (figures 7 and 8), all paddy fields have disappeared in this class and all red patches on the image belong either to very degraded 'fringe mangroves' along waterways (Sonneratia caseolaris, Avicennia officinalis, Excoecaria agallocha, Nypa fruticans, Phoenix paludosa) or to young dense planted mangroves with Rhizophora apiculata and Nypa fruticans. These mangroves have minor importance from a forestry point of view and it is impossible to determine the exact role of degraded mangroves in shrimp farming. It is however accepted that a fraction of their net production (7 to 12 tons.ha- ${ }^{-1} \cdot \mathrm{yr}^{-1}$ ) is remineralised through decomposition or exported to adjacent waters including shrimp ponds. Tidal fluxes are moving freely in main channels and in secondary canals. 20 control points are located in these zones which are densely 
populated. The average water salinity at the end of the dry season varies from 15 to $20 \%$. Ponds are under water almost all year around with the exception of short periods during which they are cleaned. They are often deprived of any mangrove tree.

In Ca Mau Province (figures 9), this class is changing rapidly. Until the year 1999, the entire region was efficiently protected from brackish water intrusion thanks to a dense network of dikes and embankments. Paddy fields were irrigated from fresh water canals. As 'tiger shrimp' aquaculture (Penaeus monodon), requires a rather high water salinity $(15-25 \%$ o), most dikes have been opened in order to permit saltish water to enter the fields in order to convert them into shrimp ponds. In class IIb the landscape, observed on the image (Tra Vinh Province), is very peculiar. On the ground we realised that the commonest land-use units are salt pans, in which small dikes, which separate the evaporation ponds, are extremely narrow $(<50 \mathrm{~cm})$. They do not appear on satellite images giving the impression of broad non partitioned territories. As the water is very clear and its depth in salt pans is lower than $25 \mathrm{~cm}$, what is observed from space is often the colour of the bottom of salt pans. The resulting reflectances on the colour composites is a light grey, indicating either terrains flooded by shallow waters or unflooded soils.

Class III: Mixed shrimp-mangrove forestry farms. Present figures extracted from satellite products show that these mangroves, essentially constituted by planted Rhizophora apiculata trees, cover $23 \%$ of this class in Ca Mau Province and $48 \%$ in Tra Vinh Province. These artificial mangroves are extremely dense $\left(>5,000\right.$ trees.ha $\left.^{-1}\right)$, younger than 15 years old, with girths smaller than $15 \mathrm{~cm}$ and heights included between 6 and $8 \mathrm{~m}$. They produce between 7 and 10 tons.ha- ${ }^{-1} \cdot \mathrm{yr}^{-1}$ of organic matter. It has been demonstrated that the net result of organic matter flow and transportation in mangrove ecosystems is the input of inorganic compounds and the export of organic products, enriching the adjacent aquatic ecosystems. This is one of the main reasons often advocated for the protection and the rehabilitation of mangroves wherever the construction of shrimp ponds occurred at an unsustainable level. The decision has been taken, by local authorities (by each Provincial People's Committee), to maintain in this class and in each farm, an acreage under mangroves of $70 \%$ of the total land-use. This ratio is almost reached in Ca Mau Province. Shrimp farming is mainly 'extensive' or 'improved extensive'. Shrimp ponds are clearly detected from space.

Class IV: Mangrove forests. In this class mangroves are protected especially for security reasons and because they play important roles for coastal protection. Nevertheless, satellite data indicate that narrow channels are often dug in these forests where some illicit shrimp aquaculture is carried out. This was confirmed by field surveys. It is here where natural mature mangroves occur with their almost genuine habitat, structure and tree flora. Their density is high $\left(>2,000\right.$ trees.ha $\left.^{-1}\right)$ and the general physiognomy is that of a dense evergreen forest ( 8 to $12 \mathrm{~m}$ high). The mean annual water salinity is higher in Ca Mau Province (20 to 30\%o) than in Tra Vinh Province (10-20\%), where the mangrove flora seems rather poor. In Ca Mau Province all common mangrove tree species of South Asian coastlines are found 
(Rhizophora, Bruguiera, Ceriops, Xylocarpus, Sonneratia, Lumnitzera racemosa Willd etc.), in spite of the destructive effects of typhoons (the latest one, called 'Linda', has destroyed most dominant trees of the top canopy, in 1997).

Class V: Sandy beaches. This is a common class found in all tropical sandy coastlines with its cosmopolitan species of trees and shrubs (Thespesia, Calophyllum, Cocos etc.) and scattered fishermen villages. However this class, which is easily detected from space, is not very extended and touristic infrastructures are not developed in this part of the Mekong delta.

\section{[Insert table 5 about here]}

\section{CONCLUSION}

From the data analysis presented here, it can be concluded that:

1) A comparison of mangrove extent in 1965, i.e. before the last Viet Nam war, and before the development of shrimp aquaculture (figure 3, table 5) and in 2001, clearly shows that the depletion of these ecosystems in Ca Mau Province is about $387 \mathrm{~km}^{2}$ (about 32\% of the initial acreage, in 1965).

2) The physical and biological properties of each land-use class, the period of the year and the incidence angle play an essential role in determining the spectral signature from the deltaic plain of the Mekong River delta. The results obtained through SPOT data analysis are interesting in this case because they provide at a first glance, essential ground units with rather clear-cut boundaries. With the exception of Can Gio Mangrove Biosphere Reserve (since January 2000, see figure 2) and mangrove ecosystems included in Class IV, all mangroves of the Mekong delta are young planted stands of Rhizophora apiculata or Nypa fruticans (less than 20 years old, due to short rotation cycles, with a trees density often higher than 5,000 ha-1).

3) The combination of satellite data analysis and field surveys have given a set of new data which complements previous results (Clough et al. 1999). Several land-use units were discriminated and delineated from space and their peculiarities in terms of land-use patterns, existing vegetation communities and determining broad ecological parameters, were stressed.

The inventory and the monitoring of dense mangrove forests, which have been planted over large stretches in the Mekong delta, is readily possible with data provided by optical sensors. One of the main methodological shortfalls is that we are not able so far to discriminate mangrove species from space. Even pure stands of Nypa fruticans and Rhizophora apiculata, located side by side, generate almost identical spectral signatures, primarily because the number of available wavelengths is insufficient and their sizes are exceedingly broad. All available space tools operating in the visible part of the spectrum lead to practically the same conclusion i.e.: the estimation of the age of each mangrove plantation and of its standing biovolume and structure is not directly possible using only space data. However they can be measured on the field and used as ancillary data for the interpretation of the digital classification.

It appears clearly now that Tra Vinh and Ca Mau Provinces are rather different concerning their potential mangrove silviculture and shrimp farming development. 
Floristically and ecologically, they are different. Satellite products are showing some key differences such as the geomorphology with sandy ridges in Tra Vinh, which are not found in Ca Mau, and the freshwater discharge which is essential in Tra Vinh Province where the two main active arms of the Mekong river reduce the water salinity, especially during the rainy season $(<15 \%)$. This is not the case in Ca Mau Province where mean water salinities $(>20 \%$ ) are significantly higher. This could explain why the floristic composition in natural mangroves is higher in Ca Mau Province. Satellites are giving a first perception of these differences. If these results are confirmed especially by hydrobiological researches, distinct management strategies have to be anticipated in each of these Provinces of the Mekong delta.

\section{REFERENCES}

ALONGI, D. M., DIXON, P., JOHNSTON, D. J., TIEN, D. V., and XUAN, T. T., 1999, Pelagic processes in extensive shrimp ponds of the Mekong delta, Viet Nam. Aquaculture, 175, 121-141.

ALONGI, D., TIRENDI, M. F. and CLOUGH, B. F., 2000, Below-ground decomposition of organic matter in forests of the mangrove Rhizophora stylosa and Avicennia marina along the arid coast of western Australia. Aquatic Botany, 68, 97-122.

ASCHBACHER, J., OFREN, R. S., DELSOL, J.P., SUSELO, T. B., and CHARRUPAT, T., 1995, An integrated comparative approach to mangrove vegetation mapping using remote sensing and GIS technologies: preliminary results. Hydrobiologia, 295, 285-294.

BLASCO, F., GAUQUELIN, T., RASOLOFOHARINORO, M., DENIS, J., AIZPURU, M., and CALDEROU, V., 1997, Recent advances in mangrove studies using remote sensing data. Australian Journal of Marine and Fresh Water Research, 49, 287-296.

CLOUGH, B. F., PHILLIPS, M., and XUAN, T. H., 1999, Mixed shrimp farmingmangrove forestry models in the Mekong delta. ACIAR-MOFI Project FIS 94/12. Main report and executive summary, Australian Institute of Marine Science, Townsville.

DE GRAAF, G. J., and XUAN, T.T., 1998, Extensive shrimp farming, mangrove clearance and marine fisheries in the southern Provinces of Viet Nam. Mangroves and salt marshes, 2, 159-166.

DWIVEDI, R. S., RAO, B. R. M., and BHATTACHARYA, S., 1999, Mapping wetlands of the Sundarban delta and its environs using ERS-1 SAR data. International Journal of Remote Sensing, 20(11), 2235-2247.

ELLISON, A. M., 2002, Macro-ecology of mangroves: large-scale patterns and processes in tropical coastal forests. TREES, 16, 181-194.

FIELD, C. D., 1996, Restoration of Mangrove Ecosystems (Okinawa: ISME).

FUCHS J., J.L. MARTIN and J. POPULUS 1998. Assessment of tropical shrimp aquaculture impact on the environment using hydrobiology, ecology and remote Sensing as helping tools for diagnosis. EEC contract RS-CT94-00284; IFREMER, Brest. 264p. 
GAO, J., 1999, A comparative study on spatial and spectral resolution of satellite data in mapping mangrove forests. International Journal of Remote Sensing, 20(14), 2823-2833.

GOND, V., BARTHOLOMÉ, E., OUATARA, F., NONGUIERMA, A., and BADO, L., 2001, Mapping and monitoring small ponds in dry-land with VEGETATION instrument, application to West Africa. VEGETATION2000 Symposium, Belgirate, 3-6 avril 2000 (Ispra: Space Application Institute, Joint Research Centre), pp. 327-334.

GREEN, E. P., CLARK, C. D., EDWARDS, A. J., and ELLIS, A., 1998, Remote sensing techniques for mangrove mapping. International Journal of Remote Sensing, 19(5), 935-956.

HAMBREY, J., 1996, Comparative economics of land-use options in mangroves. Aquaculture Asia, 1, 2, 10-14.

HONG, P. N., and SAN, H. T., 1993, Mangroves of Viet Nam. The IUCN wetlands programme. IUCN, Gland. Switzerland.

JOHNSTON, D. J.,CLOUGH, B. F., XUAN, T. T. and PHILLIPS, J. M., 1999, Mixed shrimp-mangrove forestry farming system in Ca Mau Province, Viet Nam. Aquaculture Asia, 4(2), 6-12.

JOHNSTON, D., TRONG, N. V., TIEN, D. V., and XUAN, T. T., 2000, Shrimp yields and harvest characteristics of mixed shrimp-mangrove forestry farms in southern Viet Nam: factors affecting production. Aquaculture, 188, 263284.

JUSTICE, C. O., TOWNSHEND, C. J., HOLBEN, B., and TUCKER, C. J., 1985, Analysis of the phenology of global vegetation using meteorological satellite data. International Journal of Remote Sensing, 6, 1271-1318.

LE TOAN, T., RIBBES, F., WANG, L. F., FLOURY, N., DING, K. H., KONG, J. A., FUJITA, M., and KUSORU, T., 1997, Rice crop mapping and monitoring using ERS-1 data base experiment and modeling results. IEEE Transactions on Geoscience and Remote Sensing, 35, 41-56.

LIEW, S. C., KAM, S. P., KUONG, T. P., CHEN, P., MINH, V. Q., and LIM, H., 1998, Application of multispectral ERS-2 synthetic aperture radar in delineating rice cropping systems in the Mekong River Delta, Viet Nam. IEEE Transactions on Geoscience and Remote Sensing, 36(5), 1412-1420.

LUGO, A. E., TWILLEY, R. R., PATTERSON-ZUCCA, C., 1980, The role of black mangrove forests in the productivity of coastal ecosystems in south Florida. Report to E.P.A., Corvallis Environmental Research Laboratory, Corvallis-Oregon.

MALINGREAU, J. P., TUCKER, C. J., and LAPORTE, N., 1989, AVHRR for monitoring global tropical deforestation. International Journal of Remote Sensing, 10, 855-867.

MAURAND, P., 1943, L'Indochine forestière, 2 vol. (Paris: Institut de Recherche Agronomique d'Indochine).

MINH, L. Q., TUONG, T. P., VAN MENSVOORT, M. E. F., and BOUMA, J., 1997, Contamination of surface water as affected by land-use in acid sulfate soils in the Mekong River Delta, Viet Nam. Agriculture, Ecosystems and Environment, 61, 19-27. 
MOQUILLON, C., 1950, La forêt de palétuviers de la pointe de Ca Mau. Archives, Services Forestiers, Saigon.

NAS (National Academy of Science), 1974, The effects of herbicides in South Viet Nam. Part A: Summary and Conclusion. Committee on the Effects of Herbicides in Viet communities; historical and geographical perspectives. The University of Nam. Wash, IV, 92-125.

NGUYEN TAC AN, 2002, The evolution of shrimp framing in the Mekong delta. Symposium on «shrimp farming sustainability in the Mekong Delta, practical actions », 5-8 march 2002 (Tra Vinh: Institute Oceanography Nha Trang), pp. 2-12.

ODUM, W. E. and HEALD, E. J., 1972, Trophic analysis of an estuarine mangrove community. Bull. Marine Sci., 22, 671-738.

PHAN MINH.THU, 2002, Application of Geographical Information System and Remote Sensing for mangrove status and its implication in shrimp culture activities in the Mekong delta, Viet Nam. Asian Institute of Technology, Bangkok.

PHINN, S. R., MENGES, C., HILL, G. J. E., and STANFORD, M., 2000, Optimizing Remotely Sensed Solutions for Monitoring, Modeling and Managing Coastal environments. Remote Sensing of Environment, 73, 117-132.

PRIMAVERA, J. H., 1998, Mangroves as nurseries: shrimp population in mangrove and non mangrove habitats. Estuarine Coastal Shelf Science, 46, 457-464.

RICKLEFS, R. E., and SCHUTER, D., 1993, Species diversity in ecological systems (London: Chicago Press Ltd).

RONNBACK, P., 1999, The ecological basis for the economic value of mangrove forests in seafood production. Ecological Economics, 29, 235-252.

ROSS, P., 1975, The mangrove of South Viet Nam: the impact of Military use of herbicides. Proceedings of International Symposium of Biology and Management of Mangroves, 8-11 oct. 1974 (Hawaii: Gainesville), pp. 695709.

SAENGER, P., 2002, Mangrove Ecology, Silviculture and Conservation (Dordrecht: Klüwer Ed.).

SANDERSON, P. G., 2001, The application of satellite remote sensing to coastal management in Singapore. Ambio, 30(1), 43-48.

SNEDAKER, S. C., DICKINSON, J. C., BROWN, M. S. and LAHMANN, E. J., 1998, Ubicacion de piscinas camaroneras $y$ alternativas de manejo en ecosistemas de manglares en Ecuador. PMRC (Proyecto de Manejo de Recursos Costeros), N² Serie Estudios, Ministerio de Agricultura y Ganaderia, Guyaquil-Ecuador.

SPALDING, M., BLASCO, F., and FIELD, C., 1997, Word Mangrove Atlas (Okinawa: ISME).

TEAS, H. J., and KELLY, J., 1975, Effect of herbicides on mangroves of South Viet Nam and Florida. Proceedings of International Symposium on Biology and Management of Mangroves, 8-11 oct. 1974 (Hawaii: Gainesville), pp. 719-728. 
THUYEN, L. X., 1996, La zone sud du delta du Mékong ; sédimentation actuelle et évolution récente. Thèse en Géologie Marine, $\mathrm{n}^{\circ}$ d'ordre 1605, Université de Bordeaux I, France.

TOMLINSON, P. B., 1986, The botany of mangroves (Cambridge: Cambridge University Press).

TOWNSHEND, J. R. G., and JUSTICE, C. O., 1986, Analysis of the dynamics of African vegetation using the NDVI. International Journal of Remote Sensing, 9, 187-236.

TRI, W. H., ADGER, W. N., KELLY, P. M., 1998, Natural resources management in mitigating climate impacts: mangrove restoration in Viet Nam. Global Environmental Change, 8, 49-61.

US Navy maps, 1962-1967; Combat charts at scale 1/50,000; Viet Nam. US Department of Defense, Washington. 


\section{List of figures}

Figure 1. Mekong Delta (southern Viet Nam) and location of study areas.

Figure 2. Location of main mangrove areas (250,000 ha) in the Mekong Delta in 1943 (From Hong and San 1993).

Figure 3. Location of the study area in Ca Mau Province (SPOT Scene 274/332 dated 10 April 2001) and main mangrove areas in 1965 (from maps produced by the US Dept of Navy).

Figure 4. Ombrothermic diagram of Ca Mau (Viet Nam).

Figure 5. Shrimp culture development in the Mekong Delta (adapted from Nguyen Tac An 2002).

Figure 6. SPOT data. Flow chart of the processing method.

Figure 7. A supervised classification with the Maximum Likelihood algorithm using 4 channels of SPOT $(\mathrm{P}+\mathrm{XI})$ in Tra Vinh area.

Figure 8. Main land-use classes in Tra Vinh area.

Figure 9. Main land-use classes in Ca Mau area. 


\section{List of tables}

Table 1. Some soils properties in the Mekong Delta.

Table 2. Production, area and productivity of shrimp culture in Ca Mau and Tra Vinh Provinces (From Thu 2002).

Table 3. Characteristics of SPOT 4 data.

Table 4. Present extent of mangrove ecosystems in Ca Mau and Tra Vinh Provinces (derived from figures 8 and 9).

Table 5. Acreage of mangroves and main land-use units in the study site of Ca Mau Province in 1965 (see figure 3). 
Table 1. Some soils properties in the Mekong Delta

\begin{tabular}{|c|c|c|c|c|c|c|c|c|}
\hline Province, station & Depth & $\mathrm{pH}$ & Clay & Loam & Sand & Org. Matter & $\mathrm{C}$ & $\mathrm{C} / \mathrm{N}$ \\
\hline Ca Mau 10 & $10 \mathrm{~cm}$ & 4.6 & $55 \%$ & $42 \%$ & $3 \%$ & $5 \%$ & $6.1 \%$ & 20.4 \\
Ca Mau 10 & $50 \mathrm{~cm}$ & 6.9 & $46 \%$ & $44 \%$ & $10 \%$ & $12.4 \%$ & $7.1 \%$ & 18.5 \\
\hline Ca Mau 7A & $10 \mathrm{~cm}$ & 6.7 & $60 \%$ & $36 \%$ & $3 \%$ & $30.6 \%$ & $17.8 \%$ & 22.4 \\
Ca Mau 7A & $50 \mathrm{~cm}$ & 6.5 & $53 \%$ & $44 \%$ & $3 \%$ & $32.2 \%$ & $18.7 \%$ & 31.5 \\
\hline TraVinh 15 & $10 \mathrm{~cm}$ & 6.4 & $54 \%$ & $45 \%$ & $1 \%$ & $3 \%$ & $1.5 \%$ & 14.8 \\
TraVinh 15 & $50 \mathrm{~cm}$ & 7.2 & $36 \%$ & $62 \%$ & $2 \%$ & $3.4 \%$ & $1.9 \%$ & 16.6 \\
\hline Tra Vinh 6 & $10 \mathrm{~cm}$ & 6.8 & $52 \%$ & $46 \%$ & $1 \%$ & $4.6 \%$ & $2.3 \%$ & 14.1 \\
Tra Vinh 6 & $50 \mathrm{~cm}$ & 6.9 & $51 \%$ & $47 \%$ & $2 \%$ & $2.3 \%$ & $1.3 \%$ & 13.6 \\
\hline
\end{tabular}

Table 2. Production, area and productivity of shrimp culture in Ca Mau and Tra Vinh Provinces (from Phan Minh Thu 2002)

\begin{tabular}{|c|c|c|c|c|c|c|c|c|c|}
\hline \multicolumn{2}{|c|}{ Year } & $\mathbf{1 9 9 5}$ & $\mathbf{1 9 9 6}$ & $\mathbf{1 9 9 7}$ & $\mathbf{1 9 9 8}$ & $\mathbf{1 9 9 9}$ & $\mathbf{2 0 0 0}$ & $\mathbf{2 0 0 1}$ & $\mathbf{2 0 0 2}$ \\
\hline $\begin{array}{c}\text { Production } \\
\text { (tons) }\end{array}$ & Ca Mau & 24016 & 18325 & 18932 & 16817 & 19720 & 49233 & 62000 & 73000 \\
\cline { 2 - 10 } & Tra Vinh & 3909 & - & 2150 & 1880 & 1674 & 2716 & 3324 & 4278 \\
\hline \multirow{2}{*}{$\begin{array}{c}\text { Area } \\
\text { (ha) }\end{array}$} & Ca Mau & 123041 & 104431 & 104371 & 106102 & 90511 & 153373 & 202000 & 202000 \\
\cline { 2 - 10 } & Tra Vinh & 20500 & - & 11570 & 6000 & 8480 & 9512 & 10445 & 10980 \\
\hline \multirow{2}{*}{$\begin{array}{c}\text { Productivity } \\
\text { (kg.ha-1.1.1r) }\end{array}$} & Ca Mau & 195 & 175 & 181 & 158 & 218 & 321 & 307 & 361 \\
\cline { 2 - 10 } & Tra Vinh & 191 & - & 186 & 313 & 197 & 286 & 318 & 390 \\
\hline
\end{tabular}

Table 3. Characteristics of SPOT 4 data

\begin{tabular}{|c|c|c|}
\hline Scene identification (KJ) & $274-332$ & $276-330$ \\
\hline Acquisition Date & 10 April 2001 & 22 January 2001 \\
\hline Center Location & $\mathrm{N} 8^{\circ} 48^{\prime}, \mathrm{E} 105^{\circ} 03^{\prime}$ & $\mathrm{N} 9^{\circ} 45^{\prime}, \mathrm{E} 106^{\circ} 26^{\prime}$ \\
\hline Area & \multicolumn{2}{|c|}{$60 \mathrm{~km} \times 60 \mathrm{~km}$} \\
\hline Ground Resolution & \multicolumn{2}{|c|}{ 20m (XS), 10m (P + XI) } \\
\hline Incidence Angle & R 1.2 degrees & R 11.0 degrees \\
\hline Spectral Bands & \multicolumn{2}{|c|}{$\begin{array}{c}\text { Green }(0.50-0.59 \mu \mathrm{m}) \\
\text { Red }(0.61-0.68 \mu \mathrm{m}) \\
\text { Near Infra-Red }(0.79-0.89 \mu \mathrm{m}) \\
\text { Short Wave Infra Red }(1.58-1.73 \mu \mathrm{m})\end{array}$} \\
\hline
\end{tabular}


Table 4. Present extent of mangrove ecosystems in Ca Mau and Tra Vinh Provinces (derived from figures 8 and 9)

\begin{tabular}{|c|c|c|c|c|c|c|c|c|}
\hline \multirow{2}{*}{ Land use classes } & \multicolumn{2}{|c|}{ Total area (ha) } & \multicolumn{2}{|c|}{ Mangrove area (\%) } & \multicolumn{2}{|c|}{ Water $(\%)$} & \multicolumn{2}{|c|}{ Others (\%) } \\
\hline & Ca Mau & Tra Vinh & Ca Mau & Tra Vinh & Ca Mau & Tra Vinh & Ca Mau & Tra Vinh \\
\hline $\begin{array}{l}\text { Class I } \\
\text { Paddy fields, food crops orchards }\end{array}$ & 66000 & 34000 & - & - & 95 & 16 & 5 & 84 \\
\hline $\begin{array}{l}\text { Class II } \\
\text { Shrimp ponds, salt pans and some mangrove } \\
\text { remnants }\end{array}$ & 36000 & 26000 & 7 & 18 & 93 & 82 & 0 & 0 \\
\hline $\begin{array}{l}\text { Class III } \\
\text { Mixed shrimp-mangrove forestry farms }\end{array}$ & 33000 & 10000 & 23 & 48 & 77 & 52 & 0 & 0 \\
\hline $\begin{array}{l}\text { Class IV } \\
\text { Mangrove forests }\end{array}$ & 52000 & 1100 & 55 & 90 & 45 & 10 & 0 & 0 \\
\hline $\begin{array}{l}\text { Class V } \\
\text { Sandy beaches }\end{array}$ & - & 1000 & - & - & - & 64 & - & 36 \\
\hline
\end{tabular}

Table 5. Acreage of mangroves and main land-use units in the study site of Ca Mau Province in 1965 (see figure 3)

\begin{tabular}{|l|r|r|}
\hline & number of pixels & area $\left(\mathrm{km}^{2}\right)$ \\
\hline Mangroves & 1313019 & 1206.8 \\
\hline Melaleuca thickets & 1661 & 1.5 \\
\hline Main marshy areas & 362051 & 332.8 \\
\hline Plantations & 69768 & 64.1 \\
\hline Mainly irrigated crops & 1287178 & 1183.1 \\
\hline Barren lands & 4597 & 4.2 \\
\hline Water TOTAL & 1131137 & 1039.7 \\
\hline \multicolumn{1}{|c|}{ TOT } & 3832.2 \\
\hline
\end{tabular}




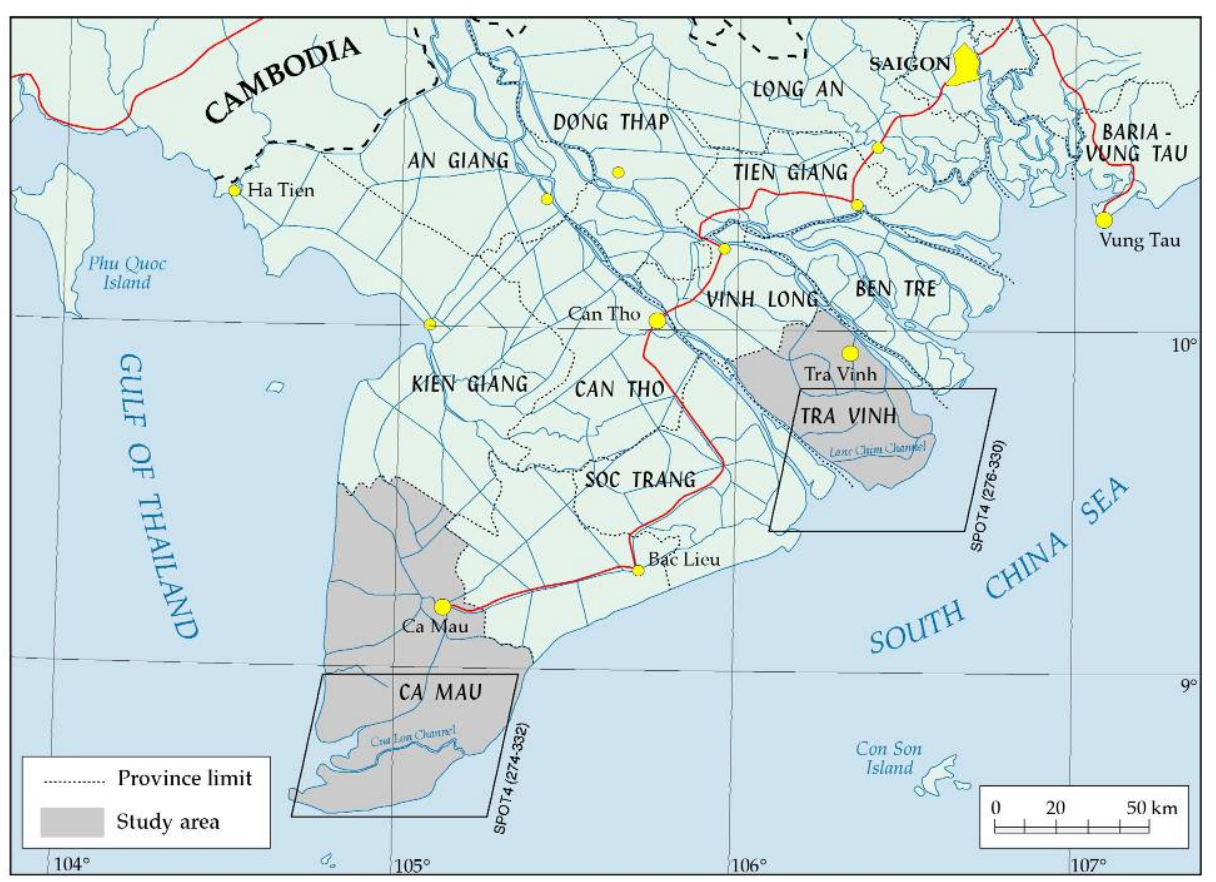

Figure 1. Mekong Delta (southern Viet Nam) and location of study areas.

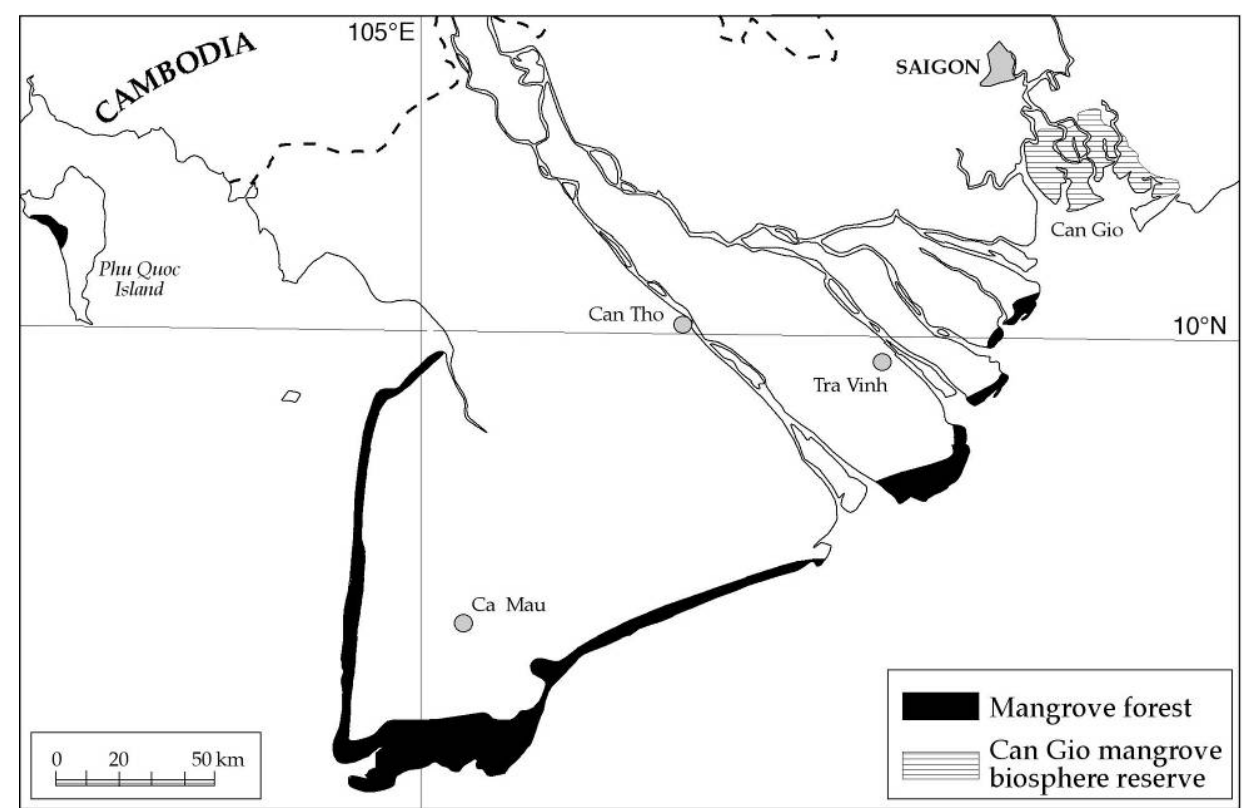

Figure 2. Location of main mangrove areas (250,000 ha) in the Mekong Delta in 1943 (From Hong and San 1993). 


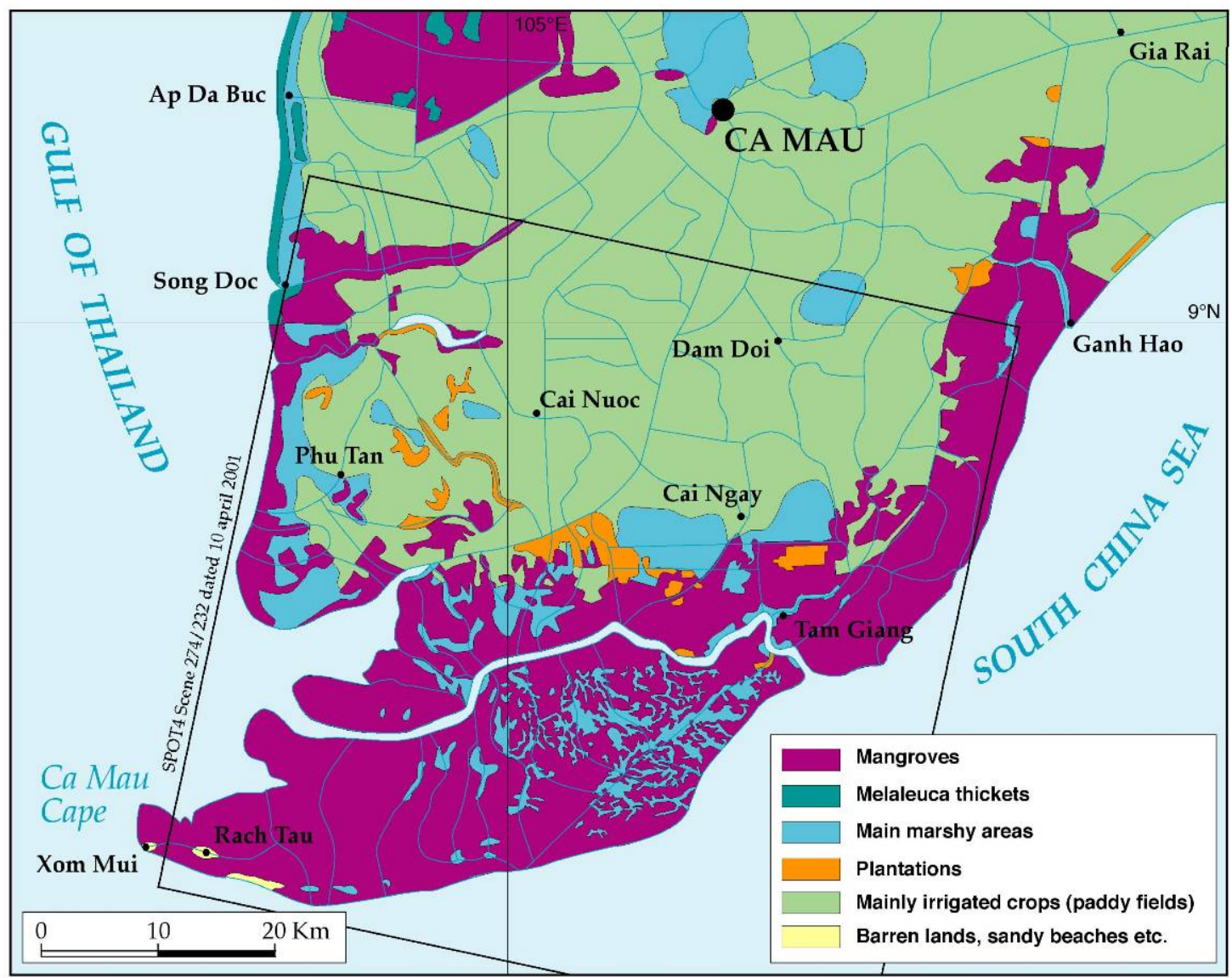

Figure 3. Location of the study area in Ca Mau Province (SPOT Scene 274/332 dated 10 April 2001) and main mangrove areas in 1965 (from maps produced by the US Dept of Navy). 


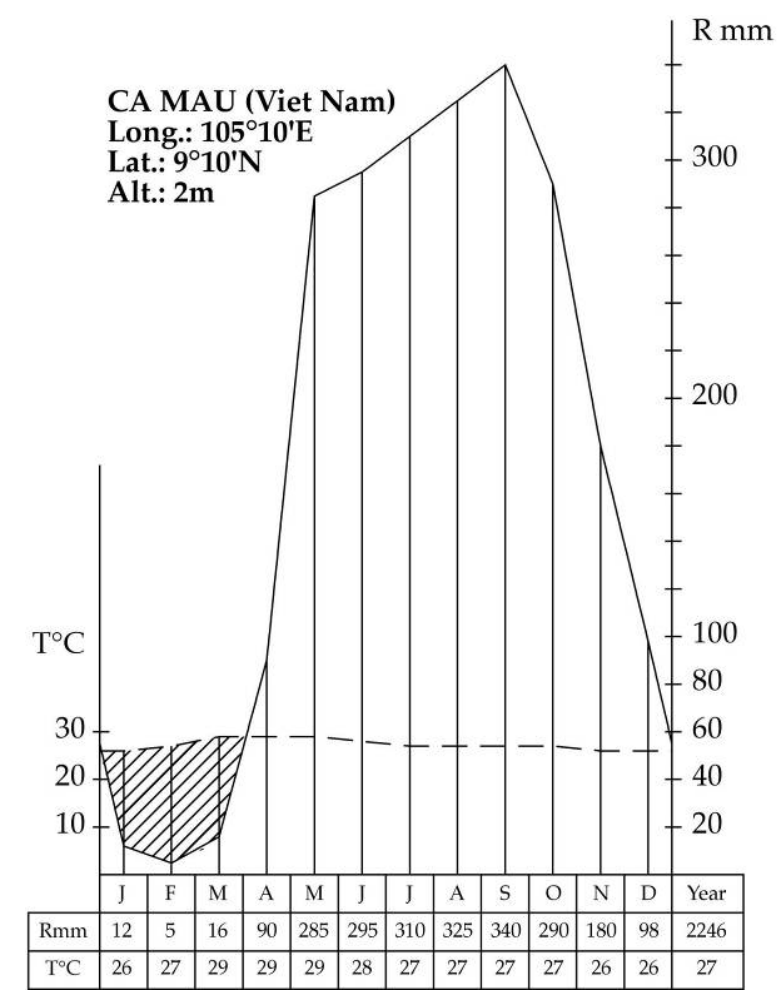

Figure 4. Ombrothermic diagram of Ca Mau (Viet Nam).

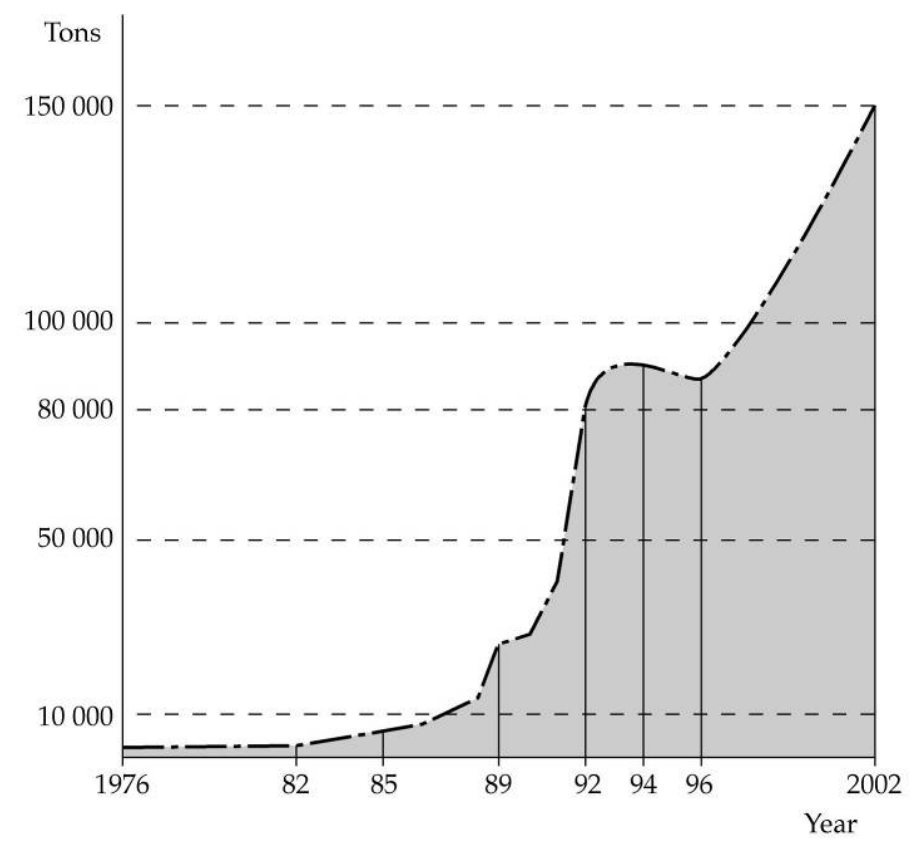

Figure 5. Shrimp culture development in the Mekong Delta (adapted from Nguyen Tac An 2002). 


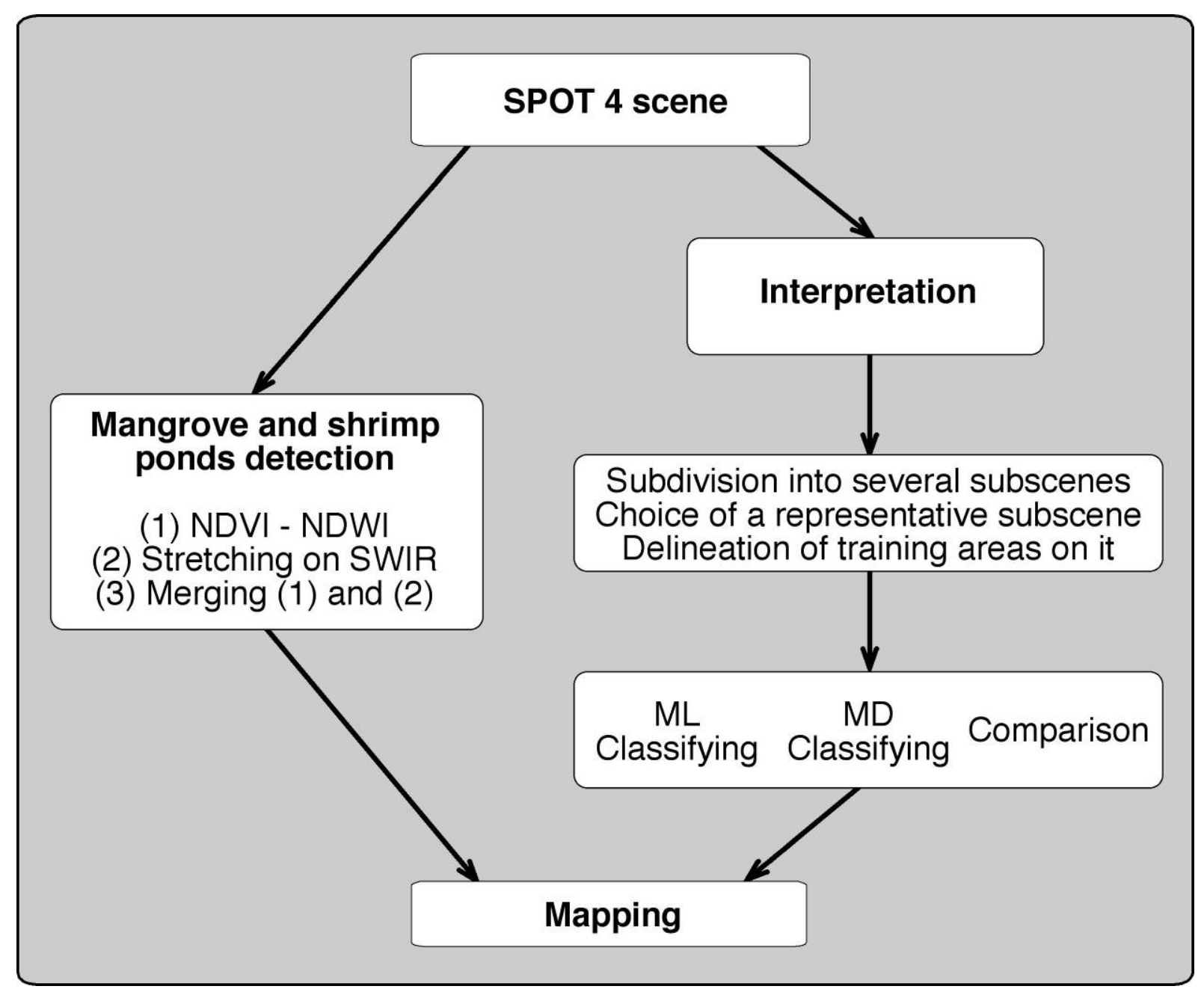

Figure 6. SPOT data. Flow chart of the processing method. 

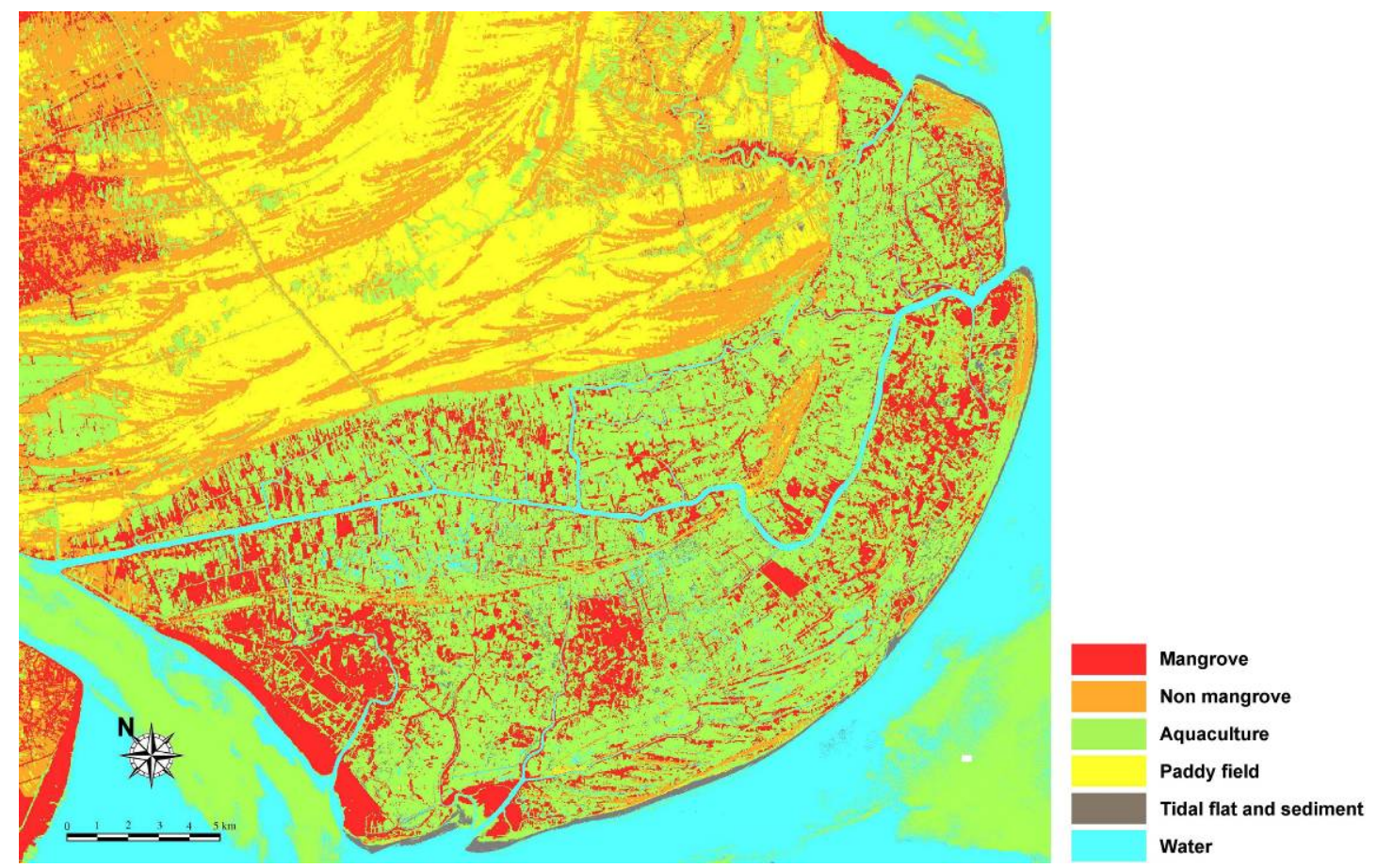

Figure 7. A supervised classification with the Maximum Likelihood algorithm using 4 channels of SPOT $(\mathrm{P}+\mathrm{XI})$ in Tra Vinh area. 


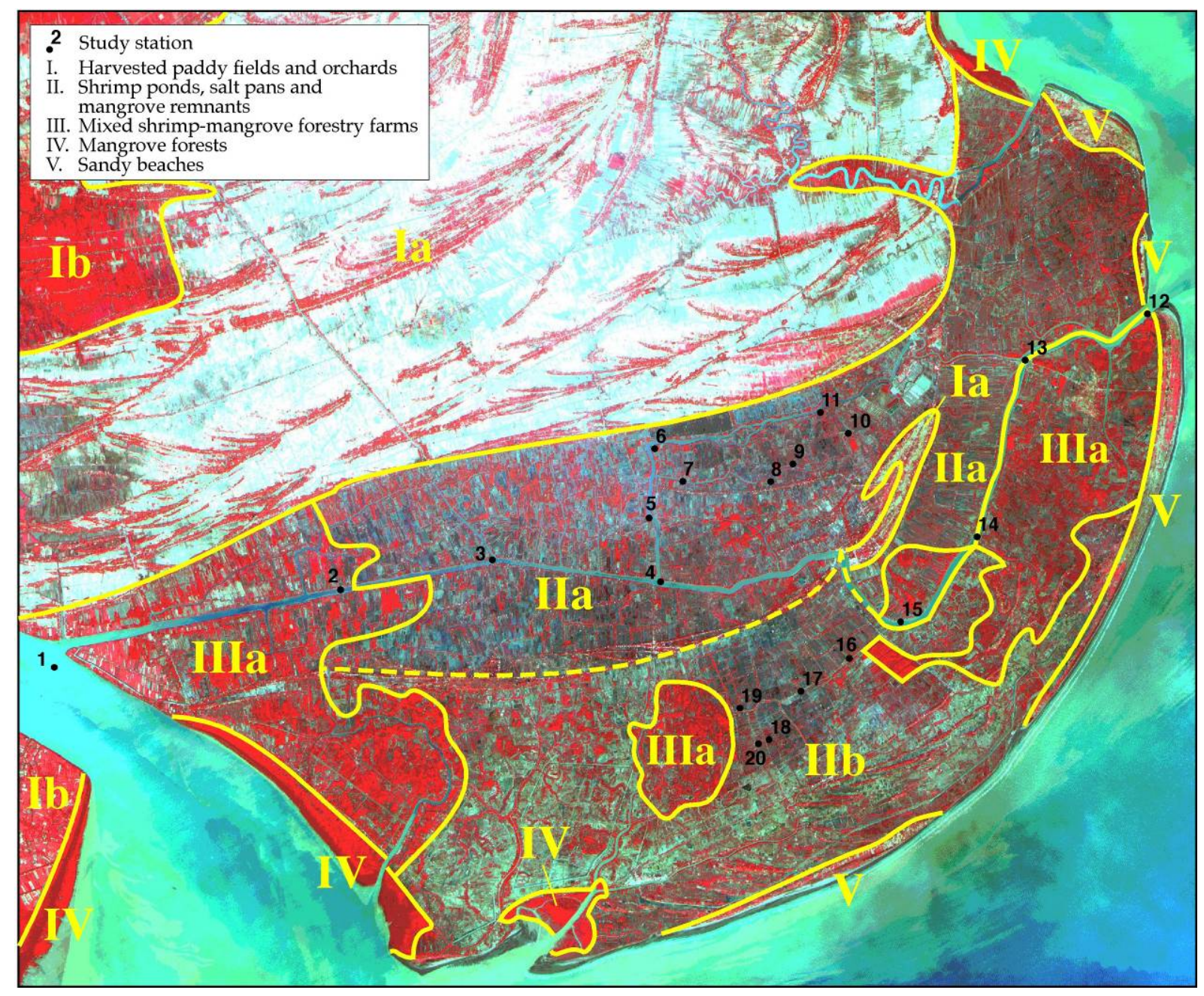

Figure 8. Main land-use classes in Tra Vinh area. 


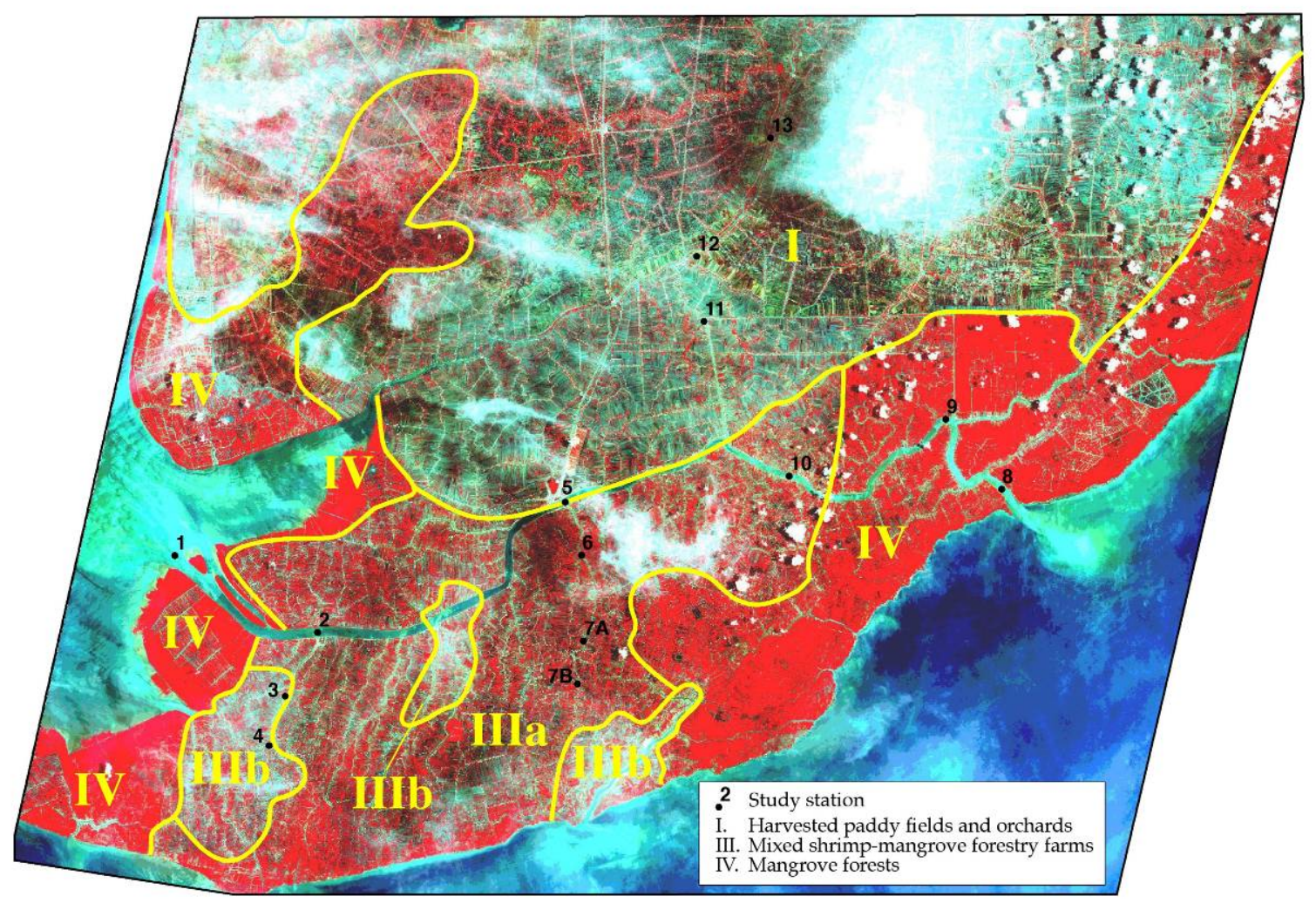

Figure 9. Main land-use classes in Ca Mau area. 